\title{
Author Correction: The Plasmodium falciparum male gametocyte protein P230p, a paralog of P230, is vital for ookinete formation and mosquito transmission
}

Catherin Marin-Mogollon ${ }^{1}$, Marga van de Vegte-Bolmer ${ }^{2}$, Geert-Jan van Gemert ${ }^{2}$, Fiona J. A. van Pul ${ }^{1}$, Jai Ramesar ${ }^{1}$, Ahmad Syibli Othman 1,3 ${ }^{1}$ Hans Kroeze ${ }^{1}$, Jun Miao ${ }^{4}$, Liwang Cui $\mathbb{D}^{4}$, Kim C. Williamson ${ }^{5}$, Robert W. Sauerwein ${ }^{2}$, Chris J. Janse ${ }^{1}$ \& Shahid M. Khan ${ }^{1}$

Correction to: Scientific Reports https://doi.org/10.1038/s41598-018-33236-x, published online 08 October 2018.

In the Supplementary Information file originally published with this Article, Supplementary Tables S1 to S4 were omitted. This error has now been corrected in the Supplementary Information that now accompanies the Article.

\begin{abstract}
(c) (i) Open Access This article is licensed under a Creative Commons Attribution 4.0 International cc) License, which permits use, sharing, adaptation, distribution and reproduction in any medium or format, as long as you give appropriate credit to the original author(s) and the source, provide a link to the Creative Commons license, and indicate if changes were made. The images or other third party material in this article are included in the article's Creative Commons license, unless indicated otherwise in a credit line to the material. If material is not included in the article's Creative Commons license and your intended use is not permitted by statutory regulation or exceeds the permitted use, you will need to obtain permission directly from the copyright holder. To view a copy of this license, visit http://creativecommons.org/licenses/by/4.0/.
\end{abstract}

(C) The Author(s) 2019

\footnotetext{
${ }^{1}$ Leiden Malaria Research Group, Parasitology, Leiden University Medical Center (LUMC), Leiden, The Netherlands. ${ }^{2}$ Department of Medical Microbiology, Radboud University Medical Center, Nijmegen, The Netherlands. ${ }^{3}$ Faculty of Health Sciences, Universiti Sultan Zainal Abidin, Terengganu, Malaysia. ${ }^{4}$ Department of Entomology, The Pennsylvania State University, University Park, Pennsylvania, United States. ${ }^{5}$ Microbiology and Immunology Department, Uniformed Services University of the Health Sciences, Bethesda, Maryland, United States. Correspondence and requests for materials should be addressed to S.M.K. (email: S.M.Khan@lumc.nl)
} 